\title{
КУЛЬТУРОЛОГИЧЕСКИЕ ИССЛЕДОВАНИЯ
}

УДК 11:316.752.4:792.01

\section{Вербицкая Галина Яковлевна}

кандидат искусствоведения, доиент кафедры истории и теории искусства Уфимской государственной академии искусств им. Загира Исмагилова, Уфа (РФ).

E-mail: galverbia@gmail.com

\section{Семенов Сергей Николаевич}

кандидат философских наук, профессор кафедры связи с общественностью Башкирского государственного университета, Уфа (РФ).

E-mail: semenov777@mail.ru

\section{РАЗРЕШЕНИЕ НЕРАЗРЕШИМОГО: ИСКУССТВО И ФИЛОСОФИЯ О «ВЕЧНЫХ» ПРОТИВОРЕЧИЯХ}

Аннотаиия. Цель работы, описанной в статье, - рассмотреть проблему философского осмысления художественных конфмиктов как модели диалектических противоречий; обосновать предвосхищающую роль искусства по отношению к теоретическому познанию через сопоставление с индивидуальным творческим актом, дающим идею решения в образно-символической форме; рассмотреть "субстанциональные" художественные конфликты в драматическом искусстве как проявление антиномистических противоречий; показать возможность разрешения данных "вечных" противоречий в конкретной ситуации путем перехода на качественно иной смысловой уровень их восприятия на примере катарсиса в новой, современной драме и подчеркнуть роль искусства в системе образования, при понимании и усвоении учебного материала, в овмадении профессией.

Методология и методики исследования. Работа выполнялась с помощью анализа драматических произведений в технике "медленного чтения" по Д. С. Аихачеву с использованием технологии дидактического дизайна по В. Э. Штейнбергу.

Результаты. Представцен опыт более чем двадцатилетней практики преподавания истории театра, теории драмы, театральной критики на театральном факультете Уфимской государственной академии искусств им. Загира Исмагилова у студентов-театроведов и режиссеров. Разработан и апроби- 
рован метод обучения анализу драмы. Рассмотрены особенности формирования специфики понятий "конфмикт" и "противоречие» в контексте философии и искусства. Раскрыто основное содержание указанных понятий, их принципиальное отличие и диалектическое соотношение, подчеркнута их роль в процессе познания и обучения. Разработана общая модель взаимодействия противоречия и конфиикта.

Практическая значимость. Материалы статьи могут быть интересны и полезны преподавателям творческих и гуманитарных вузов, а также режиссерам, драматургам и театроведам.

Ключевые слова: художественный конфиикт, противоречия, субстанциональный конфмикт, антиномистическое противоречие, катарсис, синтез противоположностей, мировосприятие, профессиональные навыки.

DOI: $10.17853 / 1994-5639-2016-1-94-110$

\title{
Verbitskaya Galina Ya.
}

Candidate of Art Sciences, Associate Professor, Department of History and Theory of Arts, Academy of Arts named after Zagir Ismagilov, Ufa (RF).

E-mail: galverbia@gmail.com

\section{Semenov Sergei $\mathbf{N}$.}

Candidate of Philosophical Sciences, Professor, Department of Public Relations, Bashkir State University, Ufa (RF).

E-mail: semenov777@mail.ru

\section{THE RESOLUTION OF THE IRRESOLVABLE: THE ART AND PHILOSOPHY OF THE «ETERNAL» CONTRADICTIONS}

\begin{abstract}
The aim of the work described in the article is to consider the problem of philosophical understanding of the art of conflict as a model of dialectical contradictions; to justify prefigures the role of art in relation to theoretical knowledge through a comparison with the individual creative act, which gives the idea of a solution in a figurative and symbolic form; to consider "substantial" artistic conflicts in the drama as a manifestation of antinomic contradictions; to show the resolution of the data "eternal" contradictions in a particular situation by shifting to a qualitatively different semantic level of their perception on the example of catharsis in a new, modern drama, and to emphasize the role of art in education, in the understanding and assimilation of educational material, to learn the profession.

Methods. Solution of the work purpose is carried out by analyzing dramatic works using the method of "slow reading" by D. S. Likhachev, and the technology of didactic design by V. E. Steinberg.
\end{abstract}


Results. The more than twenty years experience of practice teaching of theatre history and drama theory, theatre criticism at the theatre department (the Ufa State Academy of Arts named by Zagir Ismagilov) for students mastering at theatre critics and directors courses. Developed and tested teaching method to the analysis of drama. The method of training in the analysis of the drama is developed and approved. Features of specifics formation of the concepts "conflict" and "contradiction" in the context of philosophy and art are considered. The main content of the specified concepts, their fundamental difference and a dialectic ratio is disclosed, and their role in the course of knowledge and training is emphasized. The general model of interaction of a contradiction and the conflict is developed.

Practical significance. The article can be interesting and useful to teachers of creative and humanitarian universities, as well as directors, playwrights and theater critics.

Keywords: artistic conflict, contradictions, the substantial conflict, antinomic contradiction, catharsis, the synthesis of opposites, world perception, professional skills.

DOI: $10.17853 / 1994-5639-2016-1-94-110$

Известно, что многие новые формы постижения и осмысления мира сначала зарождаются в искусстве, а мишь потом развиваются в фимософско-научной, научно-теоретической сферах и в опредеменной мере стимумируют это развитие. Этой тематике посвящен целый ряд гцубоких и ценных работ. Однако недостаточно проработанными представляются следующие вопросы: каковы основания, глубинные причины подобного явмения в духовной культуре; как такие идеи могут применяться методомогически и инструментально в исследовании конкретных объектов; каковы практические (в частности - педагогические) следствия признания подобного положения дец?

Рассмотрению этих проблем и посвящается данная статья.

Особую, предвосхищающую роль искусства по отношению к теоретическому, в особенности к философскому, познанию наиболее активно обосновывал Ф. В. Й. Шемлинг, который писал: «Искусство служит прообразом нации, <..> оно достигло того, к чему нация только еще должна прийти" [36, с. 481]. Эта позиция поддерживается целым рядом видных мыслителей прошлого и современности, в ее поддержку приводится обширный материал из истории культуры, демонстрирующий факты предвосхищения новыми художественными течениями мировоззренческих идей и научных парадигм $[7,10,13,18,21,33]$. Полагаем, что данное явмение в духовной культуре, реальность которого мы вполне признаем, может быть глубже осмыслено и обосновано при раскрытии его содержательной связи с процессами индивидуального творчества. 
Прежде всего отметим многообразные подтверждения тому, что продукты успешных творческих актов первоначально осознаются творцом в форме некоторых образов, т. е. чувственно оформленных "предметов" в нашей психике. Описания подобных "озарений" и "инсайтов" содержатся во множестве публикаций по проблемам творчества. Однако исключительно важно то, что это не "первичные" чувственные образы реальных предметов, а "вторичные", насыщенные социально-культурными смыслами.

Символический и амлегорический характер эвристически значимых образов отмечают даже в таких экзотических сферах постижения творчества, как "практическая интуиция" и "творческие сновидения" $[6,9,14$, $27,38]$. А предметно-чувственный образ, насыщенный социально-культурными, духовными смыслами, в большей или меньшей степени носит эстетически-художественный характер. Как утвеждал А. Ф. Аосев, "художественная форма- тождество отвлеченного смысла и чувственного качества" [23, с. 110].

Эстетический эмемент научного творчества отмечается и в кцассических работах А. Пуанкаре и Ж. Адамара, посвященных интуиции в научных открытиях математиков $[1,26]$.

Почему же не только идеи художественных произведений, но и научные, технические, социальные и иные творческие прозрения возникают как эстетические образы? Ответ в том, что эти эстетико-символические образы обладают большой динамичностью и пластичностью, многомерностью, универсальностью и связаны со всеми сферами жизни, восприимчивы к противоречиям, способны в наглядной форме демонстрировать единство, синтез противоположностей. Подобный диалектический синтез часто отвергается могико-теоретическими "фимьтрами" сознания, хотя, с нашей точки зрения, именно разрешение диалектического противоречия в целостном, цогико-эстетическом образно-ценностном мышиении и является сущностью и механизмом творческого акта [29, с. 55-56].

Тем не менее необходимо осмыслить различные виды и формы данного диамектического противоречия дмя углубцения нашего понимания как человеческого творческого процесса, так и личностной и общественной жизни вообще.

Особое значение в этом плане может иметь изучение проявлений противоречий в искусстве, где они, отражая реальную жизнь, часто представлены в наиболее яркой форме художественного конфмикта. Наиболее развернутым процессуально, наглядно демонстрирующим процессы движения и разрешения противоречия является конфликт в драматическом искусстве. Категория "Конфликт" - центральная в поэтике и теории драмы. 
В обнажении противоречия видят сущность драмы (трагедии) и известные философы. Так, Ф. В. Й. Шемлинг задавался вопросом: «Как разум греков мог вынести противоречия, заключенные в их трагедиях...” [36, с. 83], а Ф. Ницше писал об открытии "двойственности, данной в самом происхождении и существе греческой трагедии как выражении двух переплетенных между собой художественных инстинктов - апоммонического и дионисийского" [25, с. 101].

$\Lambda$. С. Выготский также подчеркивал, что "драма обычно в качестве своего материала избирает борьбу", и выдемям в трагедии "тройное противоречие" - фабулы, сюжета и действующих миц [8]. Философ и драматург Ж. П. Сартр считал необходимым ставить героя драмы в "пограничную ситуацию" выбора альтернатив, включающих смерть, когда "свобода обнаруживается в наивысшей степени, поскольку она готова даже погибнуть, Аишь бы утвердить себя" [28, с. 92-94]. Более того, некоторые иссле-

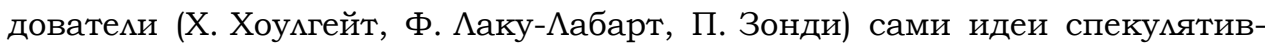
ной диалектики выводят из воздействия драматического искусства - трагедии, поскольку, по их мнению, как пишет Е. А. Найман, "трагическое противоречие предлагает модель диалектического разрешения фимософских противоречий par excellence» [24, с. 338].

Таким образом, представляется вполне обоснованной возможность углубить искусствоведческое понимание художественного конфмикта и вместе с тем расширить, обогатить и конкретизировать фимософские концепции диалектических противоречий на материале драматического искусства.

Наше внимание привлекает, в первую очередь, искусствоведческая концепция "субстанциональных конфмиктов", не имеющих явного разрешения в развязке произведения. А. П. Скафтымов [32] и Б. И. Зингерман [15], обращаясь к драматическим произведениям А. П. Чехова, отмечали, что в отличие от "классической драмы" источником конфликта является не борьба героев, а "уклад жизни" как таковой, устройство самой действительности. А В. Е. Хализев делит художественные конфликты на два типа - "казусные" и "субстанциональные" [35]. Первые близки к пониманию драматической "коммизии" по Г. В. Ф. Гегелю: они возникают в общей рамке гармонического мироустройства, имеют частные, временные, цокальные причины, содержат в себе предпосылки "снятия" и "опосредствования", т. е. разрешения возникшего противоречия, восстанавливающего нарушенную гармонию [11, c. 213-214]. Вторые связаны с вечными принципами и законами мироустройства, они уходят корнями не в чью-то зАую волю или конкретную ситуацию, а во внутренне неустранимо противоречивое бытие.

Проявления подобных "вечных" неразрешимых конфциктов можно увидеть уже в древнегреческой трагедии, в творчестве У. Шекспира и Ф. Шил- 
мера, но наиболее явно они отображаются и воплощаются в "новой драме» на рубеже XIX-XX вв. (Г. Ибсен, А. П. Чехов), а далее - в современной драматургии, в том числе в интеллектуальной драме, которую философы называют "эксистенциалистским театром" (Ж. П. Сартр, А. Камю), театре абсурда (С. Беккет, Э. Ионеско), в произведениях западных (Г. Пинтер, Ж. Жене)

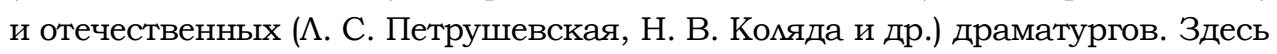
меняется само представление о драматическом начале. Источник драматизма - не некое экстраординарное событие, или особая ситуация, или уникальный герой (как в "старой" драме), а обыкновенное, обыденное, повседневное течение жизни. "Аюди обедают, только обедают, а в это время..." происходит то, что М. Метерцинк метко назвал "трагедией каждого дня». Конфцикт вечен и неразрешим, он больше и шире, чем ситуация и судьба персонажей пьесы, он существует еще до ее начала и не разрешается в ее пределах, а продолжает существовать и после ее завершения (яркий пример- финалы пьес А. П. Чехова "Дядя Ваня" и "Три сестры").

Поэтика драматургии XX в. опирается на эстетику "отрезка жизни", применяет так называемые "открытые финалы" (а иногда - и множественность возможных финалов), исходит из принципов художественного равноправия всех манифестаций жизни. Устойчивые и глубинные жизненные конфмикты (называемые "чеховскими") замедмили движение сюжета, $и$ шили действие поступательного стремления к развязке, перенесли активность персонажей во внутренний план.

Если персонажи А. П. Чехова часто драматически активны в духовном, нравственном плане, то персонажи $\Lambda$. С. Петрушевской и в особенности Н. В. Коцяды во многом духовно пассивны.

Очевидно, что в случае “субстанциональных" противоречий мы имеем дело не с гармоничным, а с дисгармоничным, диссонансным, изначально и постоянно трагическим восприятием жизни и мира. Это - не диалектика гераклитовско-гегелевского типа, постоянно видящая за трагизмом отрицание - возрождение в “снятии" как одновременном "преодомении и сохранении" в единстве итогового синтеза противоположностей.

В силу ряда исторических и культурных обстоятельств, отечественной фимософии сегодня ближе именно этот тип диалектики, или ее отрицание вообще. Но в истории фимософии сложился и другой тип диалектики, исходящей из вечных и трагических неразрешимых противоречий, который можно назвать “антиномистической диалектикой".

Именно данные фимософские концепции методологически плодотворны для осмысления субстанциональных противоречий драмы конца XIX - начала XX вв., и следует согласиться с использованием митературоведом А. Г. Коваленко понятия "антиномия", введенным И. Кантом, дмя 


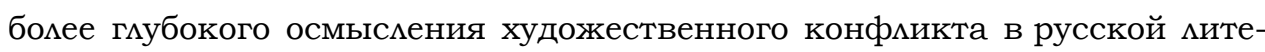
ратуре XX в. [17]. Однако антиномистическая диалектика значительно многообразнее, чем учение И. Канта о познавательных антиномиях как неразрешимых противоречиях, в которые впадает "чистый разум", стремясь перейти от внешних явлений к пониманию внутреннего, существенного, т. е. "вещей самих по себе». По И. Канту, "антиномия - не выдуманная произвольно, но основанная в природе человеческого разума, поэтому неизбежная и бесконечная..." [16, с. 232]. Однако антиномии И. Канта входят в целую традицию подобной диалектики - это "отрицательная" диалектика "апорий" Зенона Эмейского и скептиков, раннехристианские учения Тертумлиана, Августина Блаженного и Дионисия Ареопагита, буддистская диалектика "пустоты" (шуньявада) Нагарджуны и ряд других.

Если Ф. В. Й. Шемлинг и Г. В. Ф. Гегель, а затем - П. В. Фморенский, А. Ф. Аосев, К. Маркс, советские философы (Э. В. Ильенков, Г. С. Батищев) развивали диалектику синтеза, единства противоположностей, то "кантианская реставрация" вернулась к идеям "антиномизма" - у А. Шопенгауэра и Ф. Ницше. Особое место здесь занимает "патетическая диамектика" С. Кьеркегора, противопоставляемая гегелевской и отвергающая "опосредствование" и "снятие". "Датский Сократ" считал, что Аюбой выбор в вечно полярных жизненных ситуациях («ибо - либо") все равно приведет к разочарованию и отчаянию. Решение - парадоксальный и "ничем не объяснимый" скачок в области религиозной веры. Пример этого - жертва Авраама, ничем не оправданная "мудростью мира сего", но делающая его не эпическим "героем", но "рыцарем веры». Как пишет С. Кьеркегор: “Однако Авраам верил и не сомневался, он верил в противоречие» [20, с. 26].

"Трагическая", "негативная", "критическая", "антиномистическая", "интуитивная" и иные версии диалектики неразрешимых, неустранимых и вечных противоречий, отражающих уже не столько ограниченность познавательных возможностей, сколько непримиримые и грозные антиномии жизни человека и общества, дисгармоничное устройство мироздания развивались в XX в. такими мыслителями, как неогегельянцы Ж. Валь, А. Кожев во Франции, иррационалист Р. Кронер и экзистенциалист К. Ясперс в Германии, Н. А. Бердяев, И. А. Ильин и С. $\Lambda$. Франк в России.

Более глубокое осмысление искусства, субстанциональных противоречий драмы с учетом концепций и категорий данного типа диамектики представляется весьма перспективным дмя эстетики, искусствоведения. Однако и художественный конфцикт может стать важным источником философского постижения проблемы противоречия. В частности, это касается "яблока раздора" между "диалектикой синтеза" и "антиномистической диалектикой" - проблемы разрешения противоречий. Ведь взаимное 
неприятие этих двух типов диалектики связано именно с обвинениями мибо в “оправдании" и “сглаживании" трагизма жизни через "опосредования" и "синтезы", Аибо в бессильной и пассивной фиксации неустранимых противоречий. При этом если на тенденции к признанию разрешимых в диалектических синтезах противоречий мишь частными проявлениями более глубоких и разрешаемых мишь в неком запредельном Абсолюте у самого Г. В. Ф. Гегеля, в частности, в его анализе "несчастного сознания" [11, с. 112], а также "несчастных" и "печальных" комлизий, перед которыми подлинное искусство "склоняться не должно" [12, с. 218], уже обращами внимание [5], то принципы и пути разрешения антиномистических противоречий выглядят очень неясными (переход к вере, "великий отказ", полное отрицание, моральное осмысление). Как пишет С. $\Lambda$. Франк, речь идет здесь об "обоснованном на твердом решении и самоочевидно ясном узрении - свободном витании в середине или в единстве двух [противоположных. - Г. В. и С. С.] познаний - о витании, которому как раз открывается последняя истина" [34, с. 313].

Полагаем, что раскрытие определенных схем разрешения антиномистических противоречий покажет значительно больше, чем обычно предполагается единством двух типов диалектики. И "умным предметом" (М. К. Мамардашвили) дмя этого могут стать именно субстанциональные противоречия в драматическом искусстве.

Так, уже в древнегреческой трагедии (у Эсхима, Софокла, Эврипида) неизбежная гибель и кара героя в борьбе с всемогущим фатумом была, по мнению Ф. В. Й. Шемлинга, утверждением человеческой свободы и чести, ибо "в самой гибели выражается свободная воля человека" [36, с. 39].

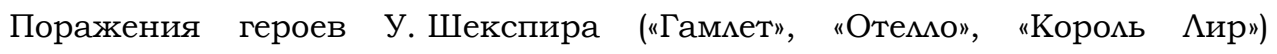
и Ф. Шимлера ("Разбойники”, “Коварство и мюбовь», "Дон Карлос») также означают и их духовно-нравственную победу.

Но наиболее значим здесь опыт "новой драмы" рубежа XIX-XX вв., современной драмы: отсутствие подиинных героев, поскольку персонажи - обычные и даже слабые мичности; отсутствие значимых событий обыденная жизнь; наконец, замедмение или почти полное отсутствие движения, действия в традиционном смысле, с отсутствием кульминации и развязки, с открытым финалом. Как же возможен здесь "катарсис", очищающее воздействие искусства? Очевидно, что ни "сопереживание" с подобными "негероями" в их часто недостойных и малозначимых поступках, ни эффект ожидания и узнавания итогов отсутствующего "действия" в развязке не могут обеспечить воздействия драматического произведения на зрителя по Аристотелю как "совершающее посредством сострадания и страха очищение (catharsis) подобных страстей» [3, с. 651]. 
Здесь мы можем опираться на три значимые дмя нашей работы концепции: "эффект монтажа", открытый кинорежиссером $\Lambda$. В. Кумешовым; "сверх" или "над" сознание как состояние осуществцения творческого акта; роли "автора" и "героя" в художественном произведении по М. М. Бахтину.

Метод монтажа $\Lambda$. В. Кумешов охарактеризовал следующим образом: "Из двух кадров возникло новое понятие, новый образ, не заключенный в них - рожденное третье ... По воле режиссера монтаж придает различный смысл содержанию" [19, с. 40]. Именно автор и режиссер современной драмы так "монтируют" - соединяют и сопоставцяют, соотносят в различных ракурсах качественно отличные аспекты "художественного бытия", что "неподвижный" по фабуле спектакль обретает иную динамику - не от действий героев, но от восприятия зрителем их и ситуаций с разных сторон.

А эту возможность "Увлечь души" зрителей в аристотелевский катарсис без привлечения их внимания к действиям, борьбе героев дает отмеченное М. М. Бахтиным соотношение “автора" (мы добавим здесь и режиссера) и "героя" в художественном произведении.

По М. М. Бахтину, "живые моменты, участники события произведения" - это "герой" и "автор-зритель" (т. е. зрителя он связывает не c "героем", а именно с "автором", что принципиально важно). "Герой" для "автора-зрителя" - принципиально "другой", воспринимаемый извне, а не объект дмя отождествления. Как пишет М. М. Бахтин: "Только другой как таковой может быть ценностным центром художественного видения, а следовательно, и героем произведения, только он может быть существенно оформлен и завершен..." [4, с. 163]. А вот “автор" как организующий и оформляющий компонент произведения, по мнению М. М. Бахтина, занимает другую позицию: «Автор не только видит и знает все то, что видит и знает каждый герой в отдельности и все герои вместе, но и дальше их, причем он видит и знает нечто такое, что им принципиально недоступно, и в этом всегда определенном и устойчивом избытке видения и знания автора по отношению к каждому герою и находятся все моменты завершения целого - как героев, так и совместного события их жизни, то есть цемого произведения" [4, с. 14]. Этим избытком видения жизни и делится автор со зрителем, позволяя ему не просто (как в реальной жизни) сопереживать героям, а понять, почувствовать общий смысл художественного произведения, ситуации, со-бытия. Это и есть сущность катарсиса как разрешения диалектического противоречия, как усмотрение невыразимого в рассудочных понятиях высшего смысла и единства трагически несовместимых противоположностей, "вечного" конфцикта. При этом катарсис - явцение эстетическое по своей природе, причем не 
только в искусстве. Дело в том, что мюбой творческий акт синтеза противоположностей (в том числе и в плане усмотрения высшего смысла их несовместимости) происходит не на уровне бес- и подсознательного (т. е. биологических и социальных стереотипов и автоматизмов), а на уровне сверх- или надсознательного [2, 30], реализующего творчество как целостное, всецело культурное мышление на уровне принципиальных порождающих схем и норм культуры.

Таким образом, субстанциональный художественный конфликт приводит в современной драме к катарсису не через развязку или прямой синтез, а через монтажное сопоставцение разцичных пластов бытия выходом зрителя при содействии "автора", т. е. общего устройства произведения во вспышке сверхсознания на новый - высший и иной - уровень отношения к этому конфмикту и к Бытию в цемом.

Можно согласиться с Ф. Ницше, считавшим: «Метафизическое утешение, с которым ... нас отпускает всякая истинная трагедия, то утешение, что жизнь в основе вещей, несмотря на всю смену явлений, несокрушимо могущественна и радостна...” [25, с. 81]. Подобным образом характеризуют "последнее слово" философии Аристотеля "в цемом" как эйдетический катарсис А. Ф. Аосев и А. А. Тахо-Годи: "Трагическое очищение в том и заключается, что гибель героев пробуждает в нас ощущение высшей справедливости и сознание высшей действительности, которая не смогла прямым и буквальным способом осуществиться в материальной жизни, но зато осуществимась косвенно" [22, с. 362].

Подобный катарсис есть особая развязка художественного конфликта, специфическая форма разрешения противоречия не путем изменения способов его проявления или развитием его внутреннего содержания, но путем трансформации перехода в иное, высшее смысловое измерение [30, с. 122-123]. Именно так разрешаются в искусстве принципиально неразрешимые субстанциональные конфмикты.

Получается, что осмысление драматического искусства в его новых формах дает философии модель разрешения вечных антиномистических противоречий жизни и бытия как бесконечного процесса поиска решений нерешаемых проблем и нового видения жизни и ее смысла.

Как в процессе обучения, так и в системе образования в целом художественно-эстетическое видение мира играет принципиально важную роль, поскольку способствует формированию гармоничного и целостного мировосприятия, эвристического аспекта в процессе познания, обучения и освоения профессии.

Поскольку в процессе обучения и более качественного усвоения материала целесообразно использовать наглядную модель, то можно пред- 
можить разработанную нами универсальную модель конфликтообразования, так как искусство есть модель жизни.

На рисунке представлена схема формирования конфликта из противоречий с эстетических позиций как универсальной модели конфмиктообразования с помощью технологии дидактического дизайна [37]: ЭС 1, $2,3 \ldots \mathrm{n}$ - экстраординарные события как источник драматизма; OC 1,2 , $3 \ldots \mathrm{n}$ - обыденные события как источник драматизма; КН 1, 2, 3...n - неразрешимый конфликт; KP $1,2,3 \ldots \mathrm{n}$ - разрешимый конфликт; У 1,2 , 3...n - "узем" перехода противоречия в конфликт; сценическое время время спектакля; индивидуальное время реципиента искусства - время зрителя (в идеале совпадает со временем спектакля); авторское (демиургово, художественное) время - образ времени в произведении.

Данная модель оказывается результативной практически, в особенности для обучения и работы драматургов, режиссеров и театроведов. В процессе сюжетостроения драматург конструирует событийные кинии таким образом, чтобы противоречия, заявленные в пьесе, могично и убедительно перерастали в конфликт. Так, например, в трагедии У. Шекспи-

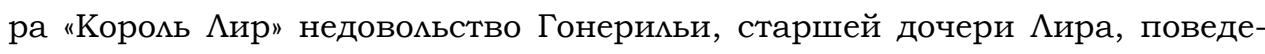
нием свиты своего отца и, как следствие, демонстративный отказ от встречи с ним - это противоречие, а ссора Аира и Гонерильи, его горечь, гнев, разочарование и поспешный отъезд - это перерастание противоречий в открытый конфмикт.

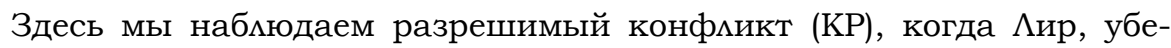
дившись в ошибочности своих прежних взглядов и двуличии старших дочерей, утверждается в мысли, что ценность человека определяется не его социальным статусом и материальным положением, а исключительно внутренними свойствами.

В случае с неразрешимым конфликтом $(\mathrm{KH})$ целесообразно привести пример из драматургии А. П. Чехова. В пьесе "Дядя Ваня" опоздание профессора Серебрякова и его молодой жены Елены Андреевны к чаю можно трактовать как противоречие, уже переросшее в конфликт (конфмикт 1). Сначала игнорируются правила и порядки, установленные в доме, а затем хладнокровно, без учета интересов большей части семейства (и, главное, дочери Серебрякова от первого брака Сони), предлагается продать все имение. Однако в случае с КН дело не ограничивается только противостоянием Войницкого (дяди Вани) и его зятя - профессора Серебрякова. Речь идет о глобальном диссонансе в укладе жизни как таковом, который не дает реализоваться талантам Войницкого и, наоборот, парадоксально способствует удаче и успеху бездарных серебряковых. 


\section{ВРЕМЕННАЯ СТРУКТУРА:}

- сценическое время

- индивидуальное время реципиента искусства (зритель, читатель) - авторское (демиургово, художественное) время

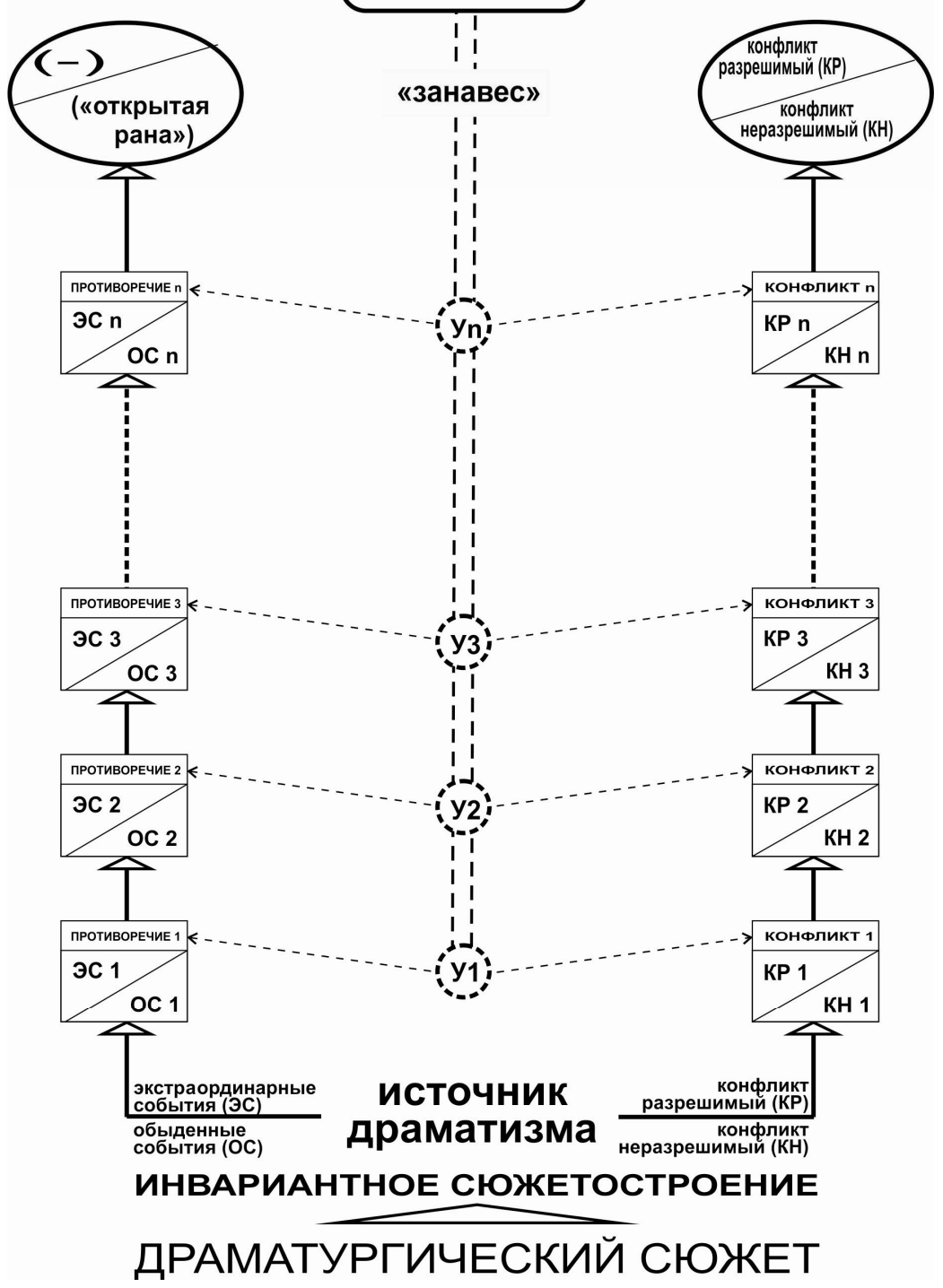

Модемь конфмиктообразования 
Такой разбор пьес (и не только классических) помогает в обучении драматургов, режиссеров и театроведов, способствуя формированию не только образного, но и конструктивно-аналитического мышления, столь необходимого дмя создания захватывающей истории.

Данный подход был успешно апробирован при обучении студентовтеатроведов и режиссеров Уфимской государственной академии искусств имени Загира Исмагимова на протяжении более чем двадцати мет, а в последние два года - на Республиканском семинаре-лаборатории современной драматургии и режиссуры, который проходим при поддержке Министерства культуры, Союза театральных деятелей и Центра современной драматургии и режиссуры Республики Башкортостан.

В результате продеманной работы за период с 2004 по 2015 г. 5 выпускников-театроведов из $17(29,4 \%)$ в настоящее время обучаются в аспирантуре по специальностям "театроведение", "культурология", "Аитературоведение", "история", а в рамках занятий семинара-лаборатории 5 молодых драматургов из 21 (23,8\%) были удостоены дипломов участников и мауреатов Всероссийских конкурсов драматургии, что, на наш взгляд, является прямым доказательством продуктивности предлагаемого подхода.

Таким образом, очевиден не только философско-теоретический, но и педагогический аспект данного исследования: Аишь приобщение к художественно-эстетическому видению мира формирует подлинно целостное, творческое, здоровое сознание человека и является значимой частью не только общекультурной, но и профессиональной подготовки высшего уровня.

Статья рекомендована к публикаиии д-ром филос. наук, проф. С. З. Гончаровым

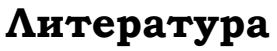

1. Адамар Ж. Исследование психологии процесса изобретения в области математики. Москва: Советское радио, 1970. 152 с.

2. А^махвердян А. Г., Мошкова Г. Ю., Юревич А. В., Ярошевский М. Г. Психология науки: учебное пособие. Москва: Флинта. 1998. 312 с.

3. Аристотель. Сочинения: в 4 т. Москва: Мысль, 1983. Т. 4. 830 с.

4. Бахтин М. М. Эстетика словесного творчества. Москва: Искусство, 1979. $424 \mathrm{c}$.

5. Валь Ж. «Несчастное сознание" в фимософии Гегеля. С.-Петербург: ВАадимир Даль, 2006. 334 с.

6. Вейн А. М. Мозг и творчество [Электрон. ресурс] // Наука и жизнь. 1983. № 3-4. Режим доступа: http://www.asatan.ru/library/ stats.mt.htm.

7. Волков Г. Н. Истоки и горизонты прогресса. Москва: Политиздат, 1976. $336 \mathrm{c}$.

8. Выготский $\Lambda$. С. Психология искусства. Москва: Педагогика, 1987. 335 с. 
9. Гарфилд П. Творческие сновидения. Москва: Евразия, 1996. 373 с.

10. Гачев Г. Д. Книга удивмений, или Естествознание глазами гуманитария, ики Образы в науке. Москва: Педагогика, 1991. 272 с.

11. Гегель Г. В. Ф. Сочинения. Москва; Аенинград: Социально-экономическая митература, 1959. Т. 4. 488 с.

12. Гегель Г. В. Ф. Сочинения: в 4 т. Москва: Искусство, 1968. Т. 1. $330 \mathrm{c}$.

13. Гулыга А. В. Искусство в век науки. Москва: Наука, 1978. 184 с.

14. Дэй $\Lambda$. Самоучитель по развитию интуиции: пер. с англ. Москва: АСТ: Астрель, 2005. 208 с.

15. Зингерман Б. И. Театр Чехова и его мировое значение. Москва: Наука, 1988. 384 с.

16. Кант И. Пролегомены. Москва; Аенинград: ОГИЗ, 1934. 379 с.

17. Коваленко А. Г. Очерки художественной конфмиктологии: Антиномизм и бинарный архетип в русской митературе XX века. Москва: РУДН, 2010. 490 c.

18. Кузнецов Б. Г. Этюды о меганауке. Москва: Наука, 1982. 136 с.

19. Кулешов $\Lambda$. В., Хохлова А. С. 50 мет в кино. Москва: Искусство, 1975. 303 c.

20. Кьеркегор С. Страх и трепет. Москва: Республика, 1993. 384 с.

21. Аихачев Д. С. Принцип историзма в изучении митературы / Взаимодействие наук при изучении митературы. Аенинград: Наука, 1981. С. 89-101.

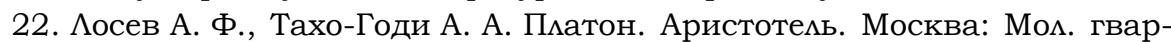
дия, 1993. 383 с.

23. Аосев А. Ф. Форма. Стиль. Выражение. Москва: Мысль, 1995. 940 с.

24. Найман Е. А. Древнегреческая трагедия как источник спекулятивного мышления // ЕХО $\Lambda$ Н (Schole). Фимософское антиковедение и классическая традиция. 2015. Т. 9. № 2. С. 331-338.

25. Ницше Ф. Сочинения: в 2 т. Москва: Мысль, 1997. Т. 1. 704 с.

26. Пуанкаре А. О науке: пер. с франц. Москва: Наука, 1983. 560 с.

27. Ротенберг В. С. Психофизиомогические аспекты изучения творчества / Художественное творчество: сборник. Аенинград: Наука, 1982. С. 53-72.

28. Сартр Ж. П. К театру ситуаций / Как всегда - об авангарде: антология фрранцузского театрального авангарда. Москва: Союзтеатр, 1992. С. 92-94.

29. Семенов С. Н. Развитие творческих способностей в процессе обучения (философско-методологические проблемы). Уфа: Гилем, 1998. 147 с.

30. Семенов С. Н. Творческое мышкение (сущность, механизмы, пути оптимизации). Уфа: РИО БашГУ, 2005.144 с.

31. Симонов П. В. "Сверхзадача" художника в свете психологии и нейрофизиологии // Психомогия процессов художественного творчества / Отв. ред. Б. С. Мейлах, Н. А. Хренов. Аенинград: Наука, 1980. С. 40-42.

32. Скафтымов А. П. Нравственные искания русских писателей. Статьи и исследования о русских классиках. Москва: Художественная митература, 1972. 543 c.

33. Уайтхед А. Избранные труды по фимософии: пер. с англ. Москва: Прогресс, 1990. 720 с.

34. Франк С. А. Сочинения. Москва: Правда, 1990. 608 с. 
35. Хализев В. Е. Драма как явление искусства. Москва: Искусство, 1978. $240 \mathrm{c}$.

36. Шемлинг Ф. В. Й. Сочинения: в 2 т. Москва: Мысль, 1987. Т. 1. 637 с.

37. Штейнберг В. Э. Дидактическая многомерная технология + дидактический дизайн (поисковые исследования). Уфа: БГПУ, 2007. 136 с.

38. Krippner S. Dreams and Creativity / Encyclopedia of Creativity. San Diego: Academic Press, 1999. Vol. 1. P. 591-596.

\section{References}

1. Hadamard J. Issledovanie psihologii processa izobretenija $\mathrm{v}$ oblasti matematiki. [The psychology of the process of the invention in the field of mathematics]. Moscow: Publishing House Sovetskoe radio. [Soviet Radio]. 1970. 152 p. (In Russian)

2. Allakhverdyan A. G., Moshkov G. Y., Yurevich A. V., Yaroshevsky M. G. Psihologija nauki. [The psychology of science]. Moscow: Publishing House Flinta.1998. 312 p. (In Russian)

3. Aristotle. Sochinenija. [Writings]. In 4 volumes. V. 4. Moscow: Publishing House Mysl'. [Thought]. 1983. 830 p. (In Russian)

4. Bakhtin M. M. Jestetika slovesnogo tvorchestva. [Aesthetics of verbal creativity]. Moscow: Publishing House Iskusstvo. [Art]. 1979. 424 p. (In Russian)

5. Val J. "Neschastnoe soznanie" v filosofii Gegelja. ["Unhappy consciousness" in Hegel's philosophy]. St.-Petersburg: Publishing House Vladimir Dahl, 2006. 334 p. (In Russian)

6. Wayne A. The brain and creativity. Nauka i zhizn'. [Science and Life]. 1983. № . 3-4. Available at: http://www.asatan.ru/library/ stats.mt.htm. (In Russian)

7. Volkov G. N. Istoki i gorizonty progressa. [Sources and horizons of progress]. Moscow: Publishing House Politizdat, 1976. 336 p. (In Russian)

8. Vygotsky L. S. Psihologija iskusstva. [Psychology of art]. Moscow: Publishing House Pedagogika. [Pedagogy]. 1987. 335 p. (In Russian)

9. Garfield P. Tvorcheskie snovidenija. [Creative dreams]. Moscow: Publishing House Evrazija. [Eurasia]. 1996. 373 p. (In Russian)

10. Gachev G. D. Kniga udivlenij, ili Estestvoznanie glazami gumanitarija, ili Obrazy v nauke. The book of surprises, or science through the eyes of a scholar, or images in science. Moscow: Publishing House Pedagogika. [Pedagogy]. 1991. 272 p. (In Russian)

11. Hegel G. W. F. Sochinenija. [Writings]. Moscow-Leningrad: Social'no-jekonomicheskaja literature. [Social and Economic Literature]. 1959. Vol. 4. $488 \mathrm{p}$ (In Russian)

12. Hegel G. W. F. Sochinenija. [Writings]. In 4 volumes. Vol. 1. Moscow: Publishing House Iskusstvo. [Art]. 1968. 330 p. (In Russian)

13. Gulyga A. B. Iskusstvo v vek nauki. [Art in the age of science]. Moscow: Publishing House Nauka. [Science]. 1978. 184 p. (In Russian)

14. Day L. Samouchitel' po razvitiju intuicii. [Tutorial on the development of intuition]. Translated from English. Moscow: Publishing House AST; Astrel', 2005. 208 p. (In Russian) 
15. Zingerman B. I. Teatr Chehova i ego mirovoe znachenie. [Theatre of Chekhov and his world]. Moscow: Publishing House Nauka. [Science]. 1988. 384 p. (In Russian)

16. Kant I. Prolegomeny. [Prolegomena]. Moscow-Leningrad: Ob'edinenie gosudarstvennyh knizhno-zhurnal'nyh izdatel'stv. [Union of the state book and journal publishing houses]. 1934. 379 p. (In Russian)

17. Kovalenko A. G. Ocherki hudozhestvennoj konfliktologii: Antinomizm i binarnyj arhetip v russkoj literature $\mathrm{HH}$ veka. [Essays on the art of conflict: the Antinomy and the binary archetype in Russian literature of the twentieth century]. Moscow: Rossijskij universitet druzhby narodov. [Peoples' Friendship University of Russia]. 2010. 490 p. (In Russian)

18. Kuznetsov B. G. Jetjudy o meganauke. Sketches on mega-science. Moscow: Publishing House Nauka. [Science]. 1982. 136 p. (In Russian)

19. Kuleshov L. V., Khokhlova A. S. 50 let v kino. [50 years in cinema]. Moscow: Publishing House Iskusstvo. [Art]. 1975. 303 p. (In Russian)

20. Kierkegaard S. Strah i trepet. [Fear and trembling [. Moscow: Publishing House Respublika. [Republic]. 1993. 384 p. (In Russian)

21. Likhachev D. S. Princip istorizma v izuchenii literatury. [The principle of historicism in the study of literature]. Vzaimodejstvie nauk pri izuchenii literatury. [Interaction of sciences in the study of literature]. Leningrad: Publishing House Nauka. [Science]. 1981. P. 89-101.

22. Losev A. F., Tahoe Godi A. A. Platon. Aristotel'. [Plato. Aristotle]. Moscow: Publishing House Molodaja gvardija. [Young Guard]. 1993. 383 p. (In Russian)

23. Losev A. F. Form. Stil'. Vyrazhenie. [Style. Expression]. Moscow: Publishing House Mysl'. [Thought]. 1995. 940 p. (In Russian)

24. Naiman E. A. Ancient Greek tragedy as a source of speculative thinking. $\mathrm{EXO} \Lambda \mathrm{H}$ (Schole). Filosofskoe antikovedenie $i$ klassicheskaja tradicija. [Ancient philosophy and the classical tradition]. 2015. Vol. 9. № 2. P. 331-338. (In Russian)

25. Nietzsche F. Sochinenija. [Writings]. In 2 volumes. V. 1. Moscow: Publishing House Mysl'. [Thought]. 1997. 704 p. (In Russian)

26. Poincare H. O nauke. [About science]. Translated from French. Moscow: Publishing House Nauka. [Science]. 1983. 560 p. (In Russian)

27. Rotenberg V. S. Psihofiziologicheskie aspekty izuchenija tvorchestva / Hudozhestvennoe tvorchestvo. [Physiological aspects of the study of creativity]. Leningrad: Publishing House Nauka. [Science]. 1982. P. 53-72. (In Russian)

28. Sartre J. P. K teatru situacij. [To the theater of situations]. Kak vsegdaob avangarde: antologija francuzskogo teatral'nogo avangarda. [As always - about the avant-garde: an anthology of French theatrical avant-garde]. Moscow: Publishing House Sojuzteatr, 1992. P. 92-94. (In Russian)

29. Semenov S. N. Razvitie tvorcheskih sposobnostej v processe obuchenija (filosofsko-metodologicheskie problemy). [Development of creative abilities in the process of education (philosophical-methodological problems)]. Ufa: Publishing House Gilem, 1998. 147 p. (In Russian)

30. Semenov S. N. Tvorcheskoe myshlenie (sushhnost', mehanizmy, puti optimizacii). [Creative thinking (the essence, mechanisms, ways of optimization)]. 
Ufa: Bashkirskij gosudarstvennyj universitet. [Bashkir State University]. 2005. 144 p. (In Russian)

31. Simonov P. V. "Sverhzadacha" hudozhnika v svete psihologii i nejrofiziologii. [The most important task of the artist in the light of psychology and neurophysiology]. Psihologija processov hudozhestvennogo tvorchestva. [Psychology of the processes of artistic creation]. Ed. by B. S. Meilach, N. A. Khrenov. Leningrad: Publishing House Nauka. [Science]. 1980. P. 40-42. (In Russian)

32. Skaftymov A. P. Nravstvennye iskanija russkih pisatelej. [Moral quest of the Russian writers]. Stat'i i issledovanija o russkih klassikah. [Articles and research about Russian classics]. Moscow: Chudozhestvennaja literature. [Fiction]. 1972. 543 p. (In Russian)

33. Whitehead A. Izbrannye trudy po filosofii. [Selected works on philosophy]. Translated from English. Moscow: Publishing House Progress, 1990. 720 p. (In Russian)

34. Frank S. L. Sochinenija. [Writings]. Moscow: Publishing House Pravda. [True]. 1990. 608 p. (In Russian)

35. Helisev V. E. Drama kak javlenie iskusstva. [Drama as an art]. Moscow: Publishing House Iskusstvo. [Art]. 1978. 240 p. (In Russian)

36. Schelling F. V. J. Sochinenija v 2 tomah. [Writings in 2 volumes]. Vol. 1. Moscow: Publishing House Mysl'. [Thought]. 1987. 637 p. (In Russian)

37. Shteinberg V. E. Didakticheskaja mnogomernaja tehnologija + didakticheskij dizajn (poiskovye issledovanija). [Didactic multidimensional technology + didactic design (exploratory studies)]. Ufa: Bashkirskij gosudarstvennyj pedagogicheskij universitet. [Bashkir State Pedagogical University]. BGPU, 2007. 136 p. (In Russian)

38. Krippner S. Dreams and Creativity. Encyclopedia of Creativity. Vol. 1. San Diego: Academic Press.1999. P. 591-596. (Translated from English) 